Research Article

\title{
Meat Waste Valorization through Protein Hydrolysis using Different Types of Proteases
}

\author{
Michelle Szucs, Miguel Angulo, Carlos Costa, Mạ Carmen Márquez *
}

Department of Chemical Engineering, Faculty of Chemical Sciences, University of Salamanca, Plaza de los Caídos 1-5, 37008-Salamanca, Spain; E-Mails: michelle.s@usal.es; mianve20@usal.es; ccosta@usal.es; mcm@usal.es

* Correspondence: Mạ Carmen Márquez; E-Mail: $\underline{\text { mcm@usal.es }}$

Academic Editors: Alberto Romero, Victor Perez-Puyana and Mercedes Jiménez-Rosado

Special Issue: Characterization, Recovery and Valorization of Protein Concentrates from Residues and By-products of Agri-food Industry

Recent Progress in Materials

2021, volume 3, issue 4

doi:10.21926/rpm.2104045
Received: May 12, 2021

Accepted: October 21, 2021

Published: November 08, 2021

\begin{abstract}
Five different commercial proteases (Alcalase 2.4L, Flavourzyme 1000L, Neutrase, Protamex, and PTN) were evaluated for the simultaneous recovery of protein and lipids through hydrolysis. The hydrolysis reaction was monitored using the $\mathrm{pH}$-stat procedure, in which samples were collected after 240 min of hydrolysis using each enzyme. The samples were analyzed for the degree of hydrolysis, protein hydrolysate, collagen, lipids, and fatty acids. A clear relationship was observed between the degree of hydrolysis and the amounts of recovered products. Serine endopeptidases from the microbial source (Alcalase) resulted in the maximum degree of hydrolysis (27.5\%), lipid recovery $(82.6 \%)$, and protein hydrolysates quality (average molecular weight of the hydrolysates $=472$ Dalton), followed by formulations of serine protease and metalloprotease from the microbial source (Protamex). Metalloproteases from the microbial source (Neutrase) resulted in maximum collagen recovery (87.1\%). Serine endopeptidases from the animal source (PTN) and endo/exopeptidases from the fungal source (Flavourzyme) exhibited an intermediate efficacy between Alcalase and Neutrase. In the case of all proteases, the product fatty acid profile
\end{abstract}

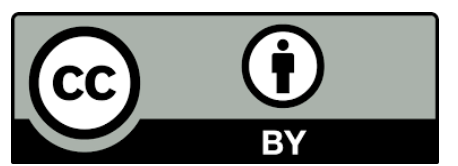

(C) 2021 by the author. This is an open access article distributed under the conditions of the Creative Commons by Attribution License, which permits unrestricted use, distribution, and reproduction in any medium or format, provided the original work is correctly cited. 
matched well with that of the meat waste, which suggests that no chemical changes occurred in the lipids after the hydrolysis with the evaluated proteases. These results suggest that hydrolysis using proteases could serve as an ecofriendly and viable alternative for obtaining additional value from meat waste.

\section{Keywords}

Protein hydrolysis; food industry; proteases; high-added value products; hydrolysates; collagen; lipids; fatty acids; meat waste

\section{Introduction}

According to the Food and Agricultural Organization (FAO), food losses are associated with the reduction in the edible food mass along a certain part of the supply chain that delivers edible food for human consumption [1]. Food losses occur during the production, post-harvest, and processing phases in the food supply chain [2]. The food losses occurring at the final stage of the food supply chain (retail and final consumption) are specifically termed "food waste" [2].

Among all food items, meat has the highest wastage rates during the retail period, accounting for approximately $70 \%$ of the retail waste produced each day [3]. This is a huge amount of waste and warrants reuse for both economic and ecological reasons.

Meat waste recovery is performed using various methods to prevent wasting the by-products that can be obtained from them. The methods currently in use include composting food waste for use as fertilizer [4] and production of meals for animals [5]. However, meat waste contains several essential nutrients such as proteins and lipids $[3,5]$, which would add value to these waste products if innovative food and non-food products (cosmetics, biofuels, pharmaceutical products, surfactants...) are developed. In this context, it would be interesting to study these products to obtain additional value from the meat processing chain.

However, waste processing should be based on methodologies that do not alter the quality and properties of the waste materials. This could be achieved through enzymatic hydrolysis, which is a rapid and softer alternative to chemical or mechanical treatments. Enzymes are capable of hydrolyzing proteins, thereby allowing the production of free amino acids, short peptides, and fatty acids.

Protein hydrolysates mainly comprise di-and tri-peptides and are, therefore, superior to whole proteins and free amino acids for application in several fields, such as biotechnology [6], nutrition $[7,8]$, and cosmetics industry [9].

Collagen is an insoluble fibrous protein that is the major constituent of the bones present in retail meat waste. Hydrolysis of collagen is rather difficult compared to the hydrolysis of globular proteins present in meat waste. However, the poor hydrolysis of collagen allows the opportunity for the recovery of this collagen for commercial applications, including cosmetics manufacturing, biomedical uses, etc. [10-12].

Fatty acids are long-chain hydrocarbons containing a carboxyl group at the terminal end. Fatty acids have a wide range of applications in the energy domain, such as flow improvers for crude oils 
[13] and biofuels [14], and also in the high-end industrial applications, such as food supplements [15], cosmetics [16], pharmaceutical applications [17], and surfactants [18].

Despite the increasing demand for protein hydrolysates, collagen, and fatty acids, no studies have been conducted so far producing these using meat waste. In this context, the production of protein hydrolysates, collagen, and fatty acids through hydrolysis using proteases is a suitable approach to generate higher income from the meat waste generated from the retail stores.

Therefore, in the present work, proteolytic enzymes were evaluated for the feasibility of their application in the recovery of high-quality protein hydrolysates, collagen, and fatty acids from retail meat waste. There are different criteria based on which the most suitable enzyme for protein hydrolysis could be selected, such as equal protease activity [19] or equal mass to substrate ratio [20]. However, since the second criterion results in different final degree of hydrolysis and protein recovery levels of the hydrolysates, the first criterion was adopted in the present work. The comparison of the protease products based on equal hydrolytic activity would provide greater insight into their actual efficiency in a particular hydrolytic process.

\section{Materials and Methods}

\subsection{Materials}

Meat waste was collected from a local retail meat store and the residue predominantly contained flesh, bones, fat, brain, heart, kidney, liver, lungs, and tongue. The meat waste was ground and homogenized to a size of less than $1 \mathrm{~mm}$ and then freeze-stored in small portions at $20{ }^{\circ} \mathrm{C}$. When using portions of the frozen meat waste, the portions were thawed overnight in a refrigerator at $4{ }^{\circ} \mathrm{C}$ prior to use.

Five food-grade enzymes (proteases) were employed for the hydrolysis in the present study, namely, Alcalase 2.4 L, Flavourzyme 1000 L, Neutrase 0.8 L, Protamex, and PTN 3.0 S. These enzymes were kindly donated by Novozymes A/S (Bagsvaerd, Denmark). Table 1 includes information regarding the characteristics of these proteases.

Table 1 Characteristics of the evaluated proteases.

\begin{tabular}{lllllll}
\hline ENZYME & SOURCE & $\begin{array}{l}\text { CATALYTIC } \\
\text { ACTION }\end{array}$ & CATALYTIC SIDE & $\begin{array}{l}\text { Optimum } \\
\mathbf{p H}\end{array}$ & $\begin{array}{l}\text { Optimum } \\
\mathbf{T}\left({ }^{\circ} \mathbf{C}\right)\end{array}$ & $\begin{array}{l}\text { Activity } \\
(\mathbf{A U} / \mathbf{g})\end{array}$ \\
\hline Alcalase & Bacillus sp. & Endopeptidase & Serine protease & $7.0-9.0$ & $40-70$ & 2.4 \\
Neutrase & Bacillus sp. & Endopeptidase & Metalloprotease & $7.0-9.0$ & $20-60$ & 6.0 \\
Protamex & Bacillus sp. & Endopeptidase & $\begin{array}{l}\text { Metalloprotease } \\
\text { + Serine protease }\end{array}$ & $5.0-7.0$ & 50 & 0.8 \\
Flavouryme & $\begin{array}{l}\text { Aspergillus } \\
\text { sp. }\end{array}$ & $\begin{array}{l}\text { Endo } \\
\text { exopeptidase }\end{array}$ & Amino peptidase & $5.0-7.5$ & $40-50$ & 0.8 \\
PTN & Animal & Endopeptidase & Serine protease & $6.0-8.0$ & $50-65$ & 1.5 \\
\hline
\end{tabular}

All chemicals were of analytical grade. 


\subsection{Analytical Methods}

Meat waste and the hydrolyzed samples were analyzed for protein, collagen, lipids, and fatty acids. Total $\mathrm{N}$ content was determined using the Kjeldahl method according to the AOAC method 981.10 [21]. The protein content was subsequently calculated from the Kjeldahl $\mathrm{N}$ using a factor of 6.25 [22]. Collagen was quantified through hydroxyproline determination (AOAC method 990.26) [21]. The lipid content was determined using petroleum ether extraction (AOAC method 960.39) [21]. The fatty acid composition of the isolated lipids was determined using the AOAC standard method 996.06 [23], the procedure of which involved hydrolytic extraction, methylation, and capillary GC-FID analysis of the resulting fatty acid methyl esters (FAMEs).

All measurements were performed in triplicate and the results were averaged. The final results were expressed as mean \pm standard deviation.

\subsection{Protein Hydrolysis}

The hydrolysis reaction was conducted in a well-stirred batch reactor with a capacity of $0.5 \mathrm{~L}$ and controlled magnetic stirring, temperature, and $\mathrm{pH}$. An amount of $50 \mathrm{~g}$ of meat waste was added to the reaction vessels containing distilled water to prepare a substrate concentration of $17.5 \mathrm{~g} / \mathrm{L}$ of protein. The suspension was adjusted to the appropriate temperature $\left(50^{\circ} \mathrm{C}\right)$ and $\mathrm{pH}(8.0)$ prior to adding the proteases; the temperature and $\mathrm{pH}$ were selected according to the optimal values for most of the evaluated enzymes (refer to Table 1). Once the proteases were added to the reaction vessels (protease concentration in the reactor $=2.81 \mathrm{UA} / \mathrm{L}$ ), the $\mathrm{pH}$ of the reaction was constantly monitored and adjusted to the desired value by adding $2 \mathrm{~N} \mathrm{NaOH}$ every time the $\mathrm{pH}$ decreased 0.1 units from the desired value. The volume of $\mathrm{NaOH}$ consumed was used for calculating the degree of hydrolysis (DH) using the following formula [22]:

$$
D H(\%)=\frac{\text { Number of peptide bonds cleaved }}{\text { Total number of peptide bonds }} \times 100=\frac{B \cdot N_{b}}{M_{p} \cdot \alpha \cdot h_{\text {tot }}} \times 100
$$

where $B$ denotes the volume of $\mathrm{NaOH}$ consumed ( $\mathrm{mL}$ or $\mathrm{L}$ ), $N_{b}$ denotes the normality of $\mathrm{NaOH}, M_{p}$ denotes the initial mass of protein in the reactor ( $\mathrm{g}$ or $\mathrm{kg}$ ), $\alpha$ is the average degree of dissociation of the $\alpha-\mathrm{NH}_{2}$ groups released during the hydrolysis $\left(1 / \alpha=1.1\right.$ at $\mathrm{pH} 8.0$ and $\left.50{ }^{\circ} \mathrm{C}\right)$, and $h_{\text {tot }}$ represents the total number of peptide bonds in the protein substrate $(7.6 \mathrm{meqv} / \mathrm{g}$ or eqv $/ \mathrm{kg}$ for meat protein) [22].

The resulting sample was boiled at $95-97^{\circ} \mathrm{C}$ for $20 \mathrm{~min}$ to deactivate the protease and pasteurize the mixture, followed by centrifugation at $9000 \mathrm{rpm}$ for $15 \mathrm{~min}$ to separate the three phases - the lower phase (unsolubilized waste) containing the collagen, the intermediate phase (supernatant) containing the protein hydrolysate, and the upper phase containing the separated lipids.

All tests were performed in duplicate, and the significant differences $(p<0.05)$ were determined using Student's t-test.

The recovery of the products was calculated as the percentage of the total content in fresh meat waste using the following equations:

$$
\text { Collagen recovery }(\%)=\left[\frac{\text { Collagen in the unsolubilized waste }(g)}{\text { Initial collagen in the reactor }(g)}\right] \times 100
$$




$$
\begin{gathered}
\text { Hydrolyzed protein recovery }(\%)=\left[\frac{\text { Protein in the supernatant }(g)}{\text { Initial protein in the reactor }(g)}\right] \times 100 \\
\text { Lipid recovery }(\%)=\left[\frac{\text { Lipids in the upper phase after centrifugation }(g)}{\text { Initial lipids in the reactor }(g)}\right] \times 100
\end{gathered}
$$

The average peptide chain length of the hydrolysate $(P C L)$ was calculated from the $\mathrm{DH}$ value as follows [19]:

$$
P C L=\frac{100}{D H}
$$

The average molecular weight of the peptides present in the hydrolysate (MW) was calculated from PCL as follows [22]:

$$
M W=130 \cdot L C P
$$

\section{Results and Discussion}

\subsection{Characteristics of the Meat Waste}

Meat waste used in the present study had a moisture content of $45.04 \pm 1.21 \%$. The protein content in the meat waste was $19.03 \pm 0.42 \%$, and the lipid content was $68.91 \pm 1.14 \%$ (both on a dry weight basis). This was consistent with the findings of García et al. [3], who conducted a study on the characterization of the meat waste generated in 208 butchers and reported protein and lipid contents of $24.6 \pm 10.3 \%$ and $69.9 \pm 13.7 \%$, respectively.

Among the proteins, collagen content was evaluated in the meat waste in the present study and was determined to be $67.91 \pm 0.14 \mathrm{mg} / \mathrm{g}$. This amount accounted for $35.68 \%$ of the total protein content in the waste, which is consistent with the fact that collagen is the most abundant protein in mammals, constituting $25 \%$ of the total body protein, $95 \%$ of the fibrous elements of the connective tissue [24], and $90 \%$ of the bones [25]. Considering that there is a higher proportion of connective tissues and bones in meat waste compared to that in the live animal bodies, it is not surprising that the collagen content obtained in the present study slightly exceeded the usual $25 \%$ level in the body.

The fatty acid composition of the meat waste (Table 2) revealed the dominance of unsaturated fatty acids (53.36 \pm 0.33 ) over saturated fatty acids $(46.64 \pm 0.19)$. Since the existing literature provides no data on the fatty acid content in butcher waste, a bibliographic review of the studies reporting the fatty acid content in different animal meats and fats was conducted [26-41]. The review revealed that the fatty acid content varies greatly depending on whether the sample is flesh or lard and also on the origin of the sample (beef, lamb, rabbit, chicken, etc.). All obtained data were combined, and a range of values was determined; the results are listed in Table 2. It was observed that the percentages of fatty acids obtained in the present study were specifically within the range determined based on the bibliographic values. 
Table 2 Fatty acid profile of the lipids recovered from the hydrolysis of meat waste using different types of proteases.

\begin{tabular}{ccc}
\hline Fatty acid & $\begin{array}{c}\text { Meat waste } \\
\text { Mean } \pm \text { SD }\end{array}$ & $\begin{array}{c}\text { Bibliographic values } \\
\text { Minimum-Maximum }\end{array}$ \\
\hline C14:0 & $4.25 \pm 0.09$ & $1.70-32.9$ \\
$\mathrm{C} 14: 1$ & $0.00 \pm 0.00$ & $0.00-2.38$ \\
$\mathrm{C} 15: 0$ & $0.27 \pm 0.03$ & $0.00-0.60$ \\
$\mathrm{C} 15: 1$ & $0.00 \pm 0.00$ & $0.00-1.70$ \\
$\mathrm{C} 16: 0$ & $25.45 \pm 0.26$ & $2.28-36.89$ \\
$\mathrm{C} 16: 1$ & $0.30 \pm 0.01$ & $0.00-37.9$ \\
$\mathrm{C} 17: 0$ & $3.48 \pm 0.10$ & $0.00-3.90$ \\
$\mathrm{C} 17: 1$ & $0.32 \pm 0.02$ & $0.00-0.90$ \\
$\mathrm{C} 18: 0$ & $12.85 \pm 0.24$ & $0.40-33.80$ \\
$\mathrm{C} 18: 1 \mathrm{n} 9 \mathrm{c}+\mathrm{t}$ & $24.64 \pm 0.34$ & $0.84-46.29$ \\
$\mathrm{C} 18: 2 \mathrm{n} 6 \mathrm{c}+\mathrm{t}$ & $10.50 \pm 0.27$ & $0.49-38.28$ \\
$\mathrm{C} 18: 3$ & $3.31 \pm 0.06$ & $0.25-4.71$ \\
$\mathrm{C} 20: 0$ & $0.34 \pm 0.02$ & $0.06-4.69$ \\
$\mathrm{C} 20: 1$ & $0.00 \pm 0.00$ & $0.00-2.78$ \\
$\mathrm{C} 20: 2$ & $1.76 \pm 0.05$ & $0.00-2.57$ \\
$\mathrm{C} 20: 3 n 3$ & $4.86 \pm 0.05$ & $0.07-4.82$ \\
$\mathrm{C} 20: 3 n 6+\mathrm{c} 21: 0$ & $3.88 \pm 0.08$ & $0.07-4.82$ \\
$\mathrm{C} 20: 4 n 6$ & $3.78 \pm 0.07$ & $0.03-3.83$ \\
\hline & &
\end{tabular}

\subsection{Protein Hydrolysates}

Figure 1 depicts the curves with a high initial reaction rate when there were several peptide bonds to be broken [22]. After three hours of the hydrolysis reaction, the reaction rate remained practically constant as the bonds available for hydrolysis had decreased drastically by this time. Therefore, a maximum hydrolysis reaction time of four hours was selected for subsequent analyses.

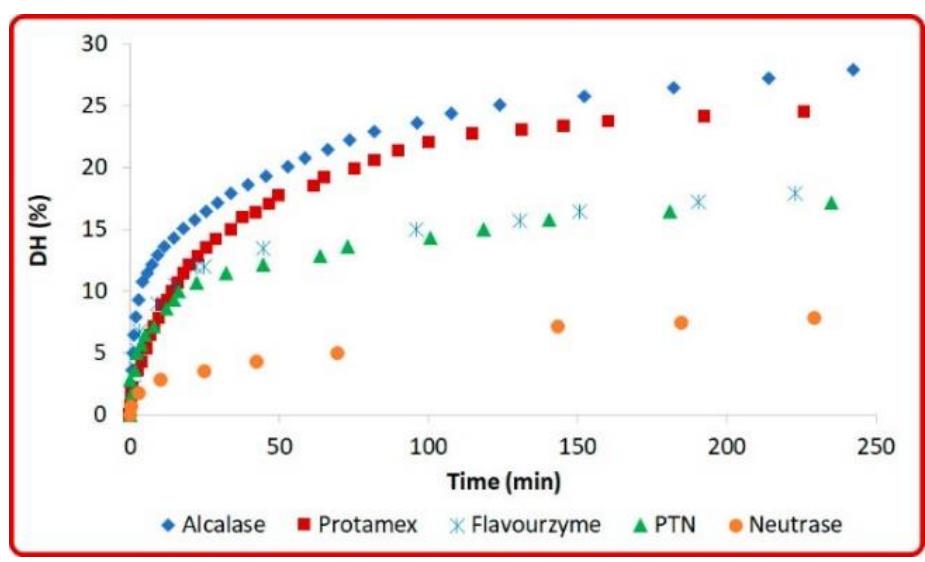

Figure 1 Effect of the type of protease on the degree of hydrolysis (DH). 
Figure 1 also revealed that DH varied between $7 \%$ and $28 \%$, with Alcalase enzyme achieving the highest $\mathrm{DH}$ value, followed by Protamex, while Neutrase exhibited the least efficiency.

The difference in the behavior of different proteases could be attributed to their characteristics that are listed in Table 1. So far, to the best of our knowledge, no studies have been conducted to compare the efficiency of different proteases in hydrolyzing meat waste. Therefore, the results obtained in the present study were compared to those of the studies conducted with fish waste with characteristics similar to those of the meat residues.

Among the three endopeptidases of bacterial origin that were evaluated in the present study (Alcalase, Neutrase, and Protamex), Neutrase was the least effective. This difference could be attributed to the critical role of serine proteases versus metalloproteases in the hydrolysis of meat waste, which is demonstrated in Figure 1, where Protamex (a preparation of serine protease and metalloprotease) exhibits an efficiency inferior to that of Alcalase while superior to that of Neutrase when aiming for a high $\mathrm{DH}$.

Among the endopeptidases of the bacterial origin, alkaline proteases (Alcalase) appear to be more suitable for the hydrolysis of meat residues compared to neutral proteases (Protamex and Neutrase).

Other authors have also reported similar results. Safari and Motamedzadegan [42] verified how, in the hydrolysis of fish waste, the DH achieved with Protamex was lower (19\%) compared to that achieved with Alcalase (34\%). Kristinsson and Rasco [19] reported that Alcalase exhibited a higher efficacy compared to Neutrase, which confirms our finding of lower efficacy of metalloproteases compared to serine proteases. Baez et al. [43] conducted a study on the hydrolysis of tilapia viscera using three different proteases (Alcalase 2.4 L, Neutrase $1.5 \mathrm{MG}$, and Flavourzyme $500 \mathrm{MG}$ ) and reported obtaining the highest $\mathrm{DH}$ of $31 \%$ with Alcalase, thereby confirming that alkaline proteases such as Alcalase exhibit higher activities compared to neutral proteases such as Flavourzyme or Neutrase.

The degrees of hydrolysis obtained in the present study also demonstrated the effect of the enzyme source on the hydrolysis reaction, according to which the serine endopeptidases from the animal source (PTN) appeared to be less suitable for the hydrolysis of butcher's waste compared to serine endopeptidases from the bacterial source (Alcalase). This was consistent with the findings of Fallah et al. [44], who conducted a study on the hydrolysis of silver carp waste and reported that Alcalase exhibits a higher DH compared to trypsin, thereby confirming the greater efficacy of bacterial proteases compared to those of animal origin.

The peptidase Flavourzyme, which is different from the other proteases evaluated in the present study in terms of its source (fungal source), catalytic activity (endo+exopeptidase), catalytic point (aminopeptidase), and neutral character, exhibited an intermediate efficacy that was similar to the efficacy of PTN. This suggested that the behavior of Flavourzyme was comparable to that of the alkaline serine proteases from animal sources and the endopeptidase activity. Kristinsson and Rasco [19] also noted the excellent potential of Flavourzyme in hydrolyzing fish proteins.

The above-stated results indicated that serine endopeptidases from bacterial sources allow achieving a higher $\mathrm{DH}$ under the previously defined operating conditions and are, therefore, most suited for the hydrolysis of protein from meat waste. Indeed, numerous studies have confirmed the efficacy of Alcalase in hydrolyzing fish waste $[42,45,46]$. 
Table 3 lists the average peptide chain lengths $(P C L)$ and average molecular weights (MW) of the peptides of the hydrolysates obtained using different proteases. The values were calculated based on the $\mathrm{DH}$.

Table 3 Average peptide chain length (PCL) and molecular weight (MW) of the hydrolysates obtained using different proteases.

\begin{tabular}{llll}
\hline Protease & $\begin{array}{l}\text { DH } \\
\text { (\%) }\end{array}$ & PCL & $\begin{array}{l}\text { MW } \\
\text { (Dalton) }\end{array}$ \\
\hline Alcalase & $27.55 \pm 0.56$ & $3.63 \pm 0.07$ & $471.87 \pm 9.57$ \\
Protamex & $24.68 \pm 0.29$ & $4.05 \pm 0.05$ & $526.74 \pm 6.19$ \\
Flavouryme & $17.49 \pm 0.66$ & $5.72 \pm 0.22$ & $743.28 \pm 28.27$ \\
PTN & $17.15 \pm 0.30$ & $5.83 \pm 0.23$ & $758.02 \pm 33.16$ \\
Neutrase & $7.50 \pm 0.47$ & $13.33 \pm 0.85$ & $1733.33 \pm 109.86$ \\
\hline
\end{tabular}

In order to be suitable for application in the food industry, the protein hydrolysates must have easy digestibility and a pleasant taste, which is achieved only when the molecular weight of the peptides composing the hydrolysates is within the range of 200-1000 Dalton). While the peptides with a higher molecular weight ( $>6000$ Dalton) cause allergies, those with molecular weight ranging between 1000 to 6000 Dalton are not suitable because of their bitter taste. Free amino acids (molecular weight < 200 Dalton) are not suitable as they are hyperosmotic and cause diarrhea [47]. Therefore, to avoid the issues of bitterness, hyperosmoticity, and allergenicity, the molecular weight distribution range of the hydrolysates should be as narrow as possible, with a high content of di-and tri-peptides and an average molecular weight of the order of 500 Dalton [48].

Therefore, the best hydrolysates would be those obtained from Alcalase and Protamex as their average molecular weight is close to 500 Dalton.

As described below, the study of the recovery of products with a higher added value from the meat waste using different proteases revealed that the degree of hydrolysis achieved was a determining parameter irrespective of the protease used.

\subsection{Hydrolyzed Protein Recovery}

As visible in Figure 2, the percentage of the unsolubilized waste remaining after the completion of the hydrolysis process depends on the degree of hydrolysis as there is an inverse relationship between these two variables. 


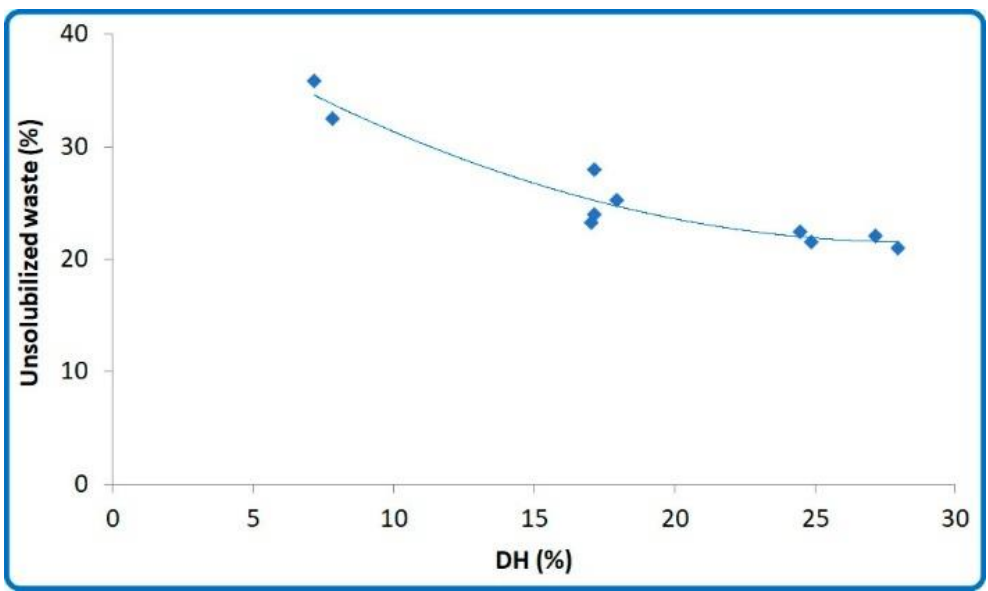

Figure 2 Effect of the degree of hydrolysis (DH) achieved using different proteases on the percentage of the unsolubilized waste remaining after hydrolysis.

This behavior is understood when the percentage of solubilized protein is considered. Unlike the percentage of unsolubilized waste, the percentage of solubilized protein exhibited an evident increase with the degree of hydrolysis (Figure 3).

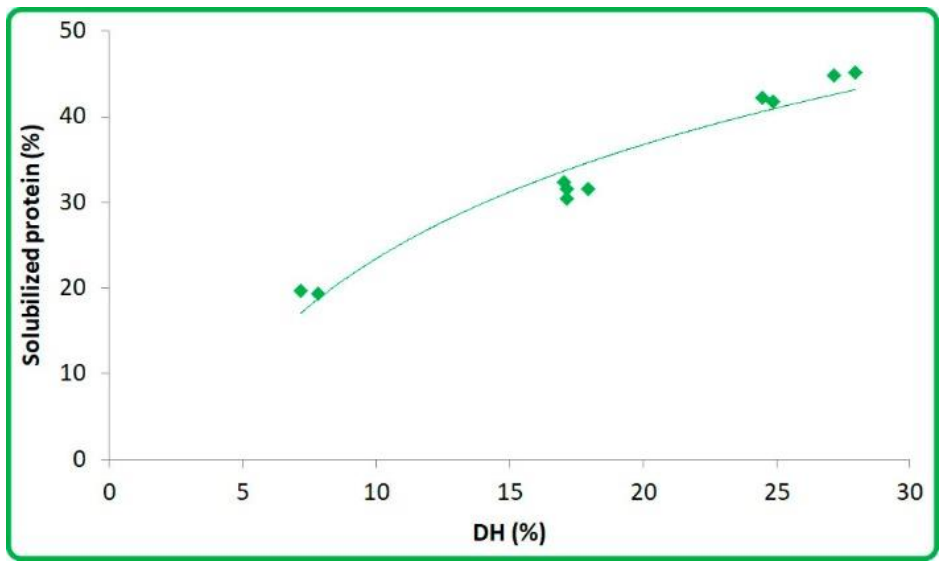

Figure 3 Effect of the degree of hydrolysis (DH) achieved using different proteases on the percentage of solubilized protein.

Native fibrous proteins are less water-soluble compared to globular proteins. Moreover, not all globular proteins are water-soluble. Among globular proteins, only albumins are naturally soluble in water. The solubility of prolamins is achievable using ethanolic solutions, that of globulins is achieved using diluted salt solutions, and that of glutelins is achieved using diluted acid or alkaline solutions [49]. In denatured proteins, peptide bonds are exposed and available for cleavage by proteases. However, native protein molecules present in solution are in a dynamic equilibrium with several distorted forms, a few of which are considerably different from the native form and, therefore, could be considered denatured and accessible to enzymatic attack.

The breaking of one or more bonds destabilizes the molecule, causing an irreversible unfolding of the protein, which exposes more peptide bonds and extensively degrades the polypeptide chains into intermediate peptides according to the kinetics characteristics of the enzyme-substrate system, thereby increasing the solubility of the molecule [50]. 
The degree of hydrolysis is indicative of the number of cleaved peptide bonds within a protein hydrolysate [51]. Therefore, the higher the $\mathrm{DH}$ value, the greater is the number of bonds that have been cleaved, the greater is the amount of solubilized protein, and the lower is the amount of unsolubilized waste, which justifies the results obtained in the present study.

Among the different proteases evaluated, Alcalase presented the highest $\mathrm{DH}$ value. This suggested that serine-type endopeptidases from bacterial sources are the proteases that allow reaching the higher solubilization of meat waste under the assessed operating conditions and are, therefore, more suited for hydrolyzing meat waste protein to obtain a higher amount of hydrolyzed protein.

\subsection{Collagen Recovery}

As in the previous case, the amount of collagen recovered strongly depends on the degree of hydrolysis achieved. As depicted in Figure 4, the percentage of collagen that remained unhydrolyzed in the unsolubilized waste is inversely proportional to $\mathrm{DH}$.

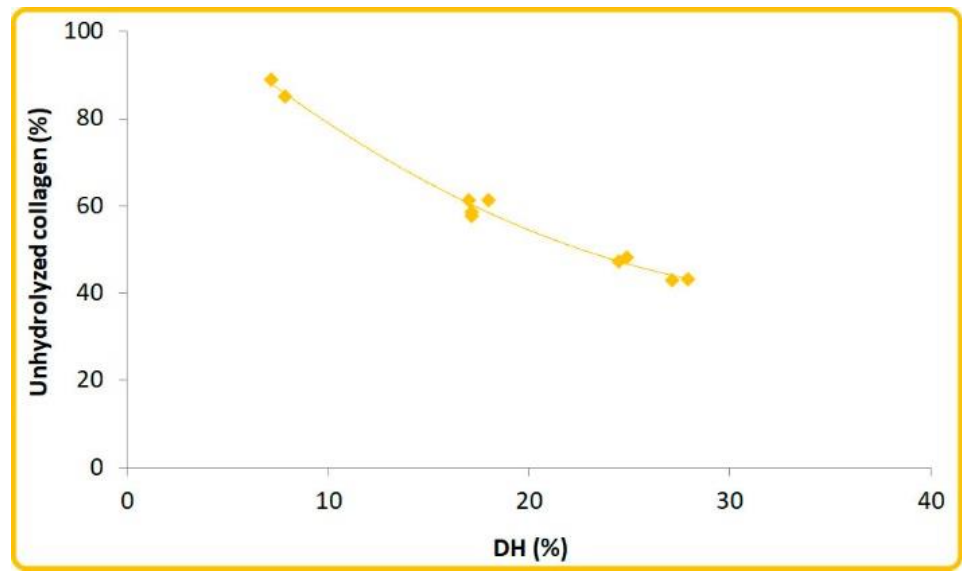

Figure 4 Effect of the degree of hydrolysis (DH) achieved using different proteases on the percentage of unhydrolyzed collagen.

Collagen is a fibrous protein, and its behavior during its hydrolysis is different from that exhibited by globular proteins. While globular proteins are hydrolyzed relatively easily due to their characteristics, native collagen exhibits less solubility and greater difficulty in hydrolyzing, causing its degree of hydrolysis to be different from that of the other proteins present in meat waste [52].

The fact that collagen is more difficult to hydrolyze implies that even though a part of it is hydrolyzed, another part remains unhydrolyzed in the solid phase and could be recovered for industrial applications. Figure 4 illustrates how the percentage of hydrolyzed collagen corresponding to a low $\mathrm{DH}$ is extremely small, implying that it had practically remained unhydrolyzed. The reverse was observed with a higher degree of hydrolysis, at which the amount of hydrolyzed collagen increased and the percentage of the total collagen that remained unhydrolyzed decreased.

As stated earlier, due to the lack of reports on meat waste hydrolysis in the literature, the findings of the present study had to be compared to the results of the studies conducted using waste with characteristics similar to those of meat waste. 
The difficulty encountered in hydrolyzing collagen has been confirmed by other authors who reported that extremely high amounts of proteases and prolonged periods of hydrolysis were required to hydrolyze collagen $[53,54]$. Studies conducted with fish skins using Alcalase have reported recovered collagen yields similar to those obtained in the present work [55].

Therefore, greater recovery yields of collagen would imply a lower degree of hydrolysis, which would be favored by metalloendopeptidase such as Neutrase that are derived from bacterial sources.

\subsection{Recovery of Lipids and Fatty Acids}

Figure 5 illustrates the trend of recovered lipid percentages upon hydrolysis using different types of proteases. The relationship between the degree of hydrolysis and the amount of recovered lipids was verified.

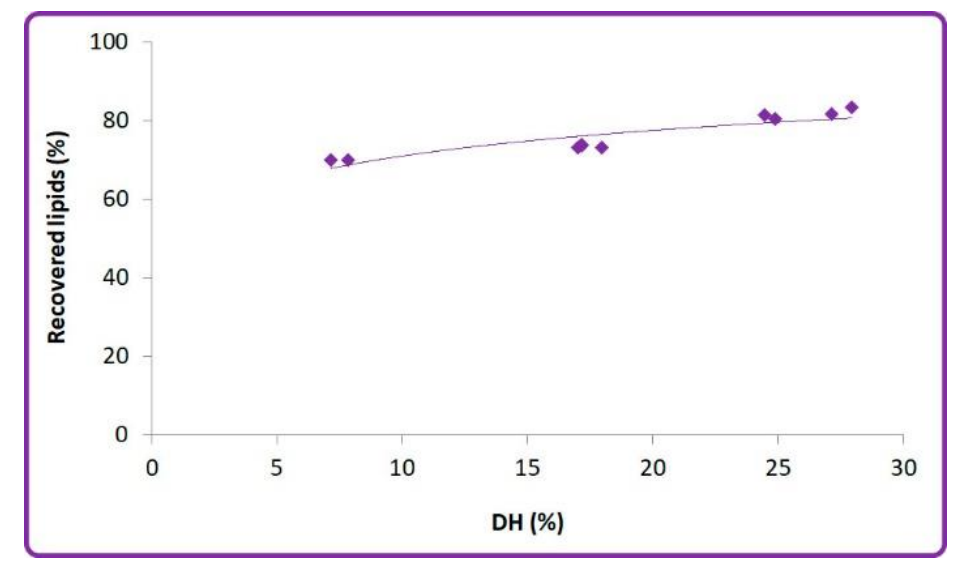

Figure 5 Effect of the degree of hydrolysis (DH) achieved using different proteases on the percentage of recovered lipid.

According to these results, Alcalase and Protamex emerge as most suited for the recovery of lipids from meat waste. This is consistent with the report by Batista et al. [56], who conducted a study on fish waste hydrolysis with characteristics similar to meat waste and observed a greater release of lipids when using Alcalase compared to when using Neutrase.

Chemically, it is the cleavage of peptide bonds by proteases that produces the release of the lipids in the meat waste. Therefore, the greater the peptide bond cleavage, the higher is the $\mathrm{DH}$, and the greater is the amount of lipids released. The relationship between $\mathrm{DH}$ and lipid recovery is asymptotic, tending to $100 \%$ recovery of lipids. Meng et al. [57] reported similar results when they evaluated five commercial proteases (Flavourzyme 1000 L, Neutrase 1.5 MG, Protamex, Alcalase 2.4 $L$, and Thermolysin) for extracting oil from rapeseed; Alcalase was reported to be the best enzyme for generating the highest free oil yield.

After lipid recovery, the profile of the fatty acids in the recovered lipids was analyzed (Table 4).

It was observed that regardless of the type of protease used, there were no significant changes in the fatty acid composition of the meat waste.

Therefore, it was inferred that hydrolysis using proteases is an effective means to recover lipids without affecting their quality. 
Unfortunately, there are no bibliographic references that could be stated here to support these results as no researchers have so far analyzed the effect of different types of proteases on the recovery of fatty acids present in meat waste. However, a comparison with the studies conducted on fish waste with characteristics similar to those of meat waste confirmed that hydrolysis with proteases does not alter the fatty acid profile of the recovered lipids [58].

Table 4 Fatty acid profile of the lipids recovered from hydrolysis using different types of proteases (expressed as the percentage of total fatty acid).

\begin{tabular}{llllll}
\hline Fatty acid & Alcalase & Neutrase & Flavourzyme & Protamex & PTN \\
\hline C14:0 & $4.23 \pm 0.04$ & $4.14 \pm 0.06$ & $4.31 \pm 0.10$ & $4.37 \pm 0.11$ & $4.25 \pm 0.10$ \\
C14:1 & $0.00 \pm 0.00$ & $0.00 \pm 0.00$ & $0.00 \pm 0.00$ & $0.00 \pm 0.00$ & $0.00 \pm 0.00$ \\
C15:0 & $0.22 \pm 0.00$ & $0.38 \pm 0.01$ & $0.39 \pm 0.01$ & $0.26 \pm 0.04$ & $0.30 \pm 0.01$ \\
C15:1 & $0.00 \pm 0.00$ & $0.00 \pm 0.00$ & $0.00 \pm 0.00$ & $0.00 \pm 0.00$ & $0.00 \pm 0.00$ \\
C16:0 & $25.36 \pm 0.28$ & $25.93 \pm 0.24$ & $25.38 \pm 0.52$ & $25.13 \pm 0.48$ & $25.24 \pm 0.18$ \\
C16:1 & $0.20 \pm 0.01$ & $0.35 \pm 0.01$ & $0.28 \pm 0.01$ & $0.58 \pm 0.03$ & $0.19 \pm 0.01$ \\
C17:0 & $3.57 \pm 0.04$ & $3.80 \pm 0.08$ & $3.41 \pm 0.04$ & $3.82 \pm 0.10$ & $3.46 \pm 0.08$ \\
C17:1 & $0.33 \pm 0.01$ & $0.38 \pm 0.03$ & $0.49 \pm 0.02$ & $0.51 \pm 0.01$ & $0.29 \pm 0.03$ \\
C18:0 & $12.98 \pm 0.17$ & $13.05 \pm 0.27$ & $12.48 \pm 0.31$ & $12.36 \pm 0.28$ & $12.84 \pm 0.37$ \\
C18:1n9c+t & $24.55 \pm 0.24$ & $24.20 \pm 0.27$ & $24.72 \pm 0.61$ & $24.38 \pm 0.78$ & $24.95 \pm 0.24$ \\
C18:2n6c+t & $10.63 \pm 0.21$ & $10.67 \pm 0.27$ & $10.83 \pm 0.25$ & $10.71 \pm 0.21$ & $10.77 \pm 0.33$ \\
C18:3 & $3.30 \pm 0.07$ & $3.26 \pm 0.01$ & $3.12 \pm 0.06$ & $3.68 \pm 0.06$ & $3.46 \pm 0.06$ \\
C20:0 & $0.34 \pm 0.01$ & $0.42 \pm 0.01$ & $0.51 \pm 0.01$ & $0.43 \pm 0.01$ & $0.38 \pm 0.03$ \\
C20:1 & $0.00 \pm 0.00$ & $0.00 \pm 0.00$ & $0.00 \pm 0.00$ & $0.00 \pm 0.00$ & $0.00 \pm 0.00$ \\
C20:2 & $1.81 \pm 0.06$ & $1.92 \pm 0.04$ & $1.98 \pm 0.04$ & $1.91 \pm 0.04$ & $2.04 \pm 0.06$ \\
C20:3n3 & $4.83 \pm 0.11$ & $4.47 \pm 0.06$ & $4.83 \pm 0.17$ & $4.51 \pm 0.10$ & $4.86 \pm 0.08$ \\
C20:3n6+c21:0 & $3.89 \pm 0.08$ & $3.12 \pm 0.14$ & $3.56 \pm 0.06$ & $3.51 \pm 0.06$ & $3.18 \pm 0.04$ \\
C20:4n6 & $3.76 \pm 0.08$ & $3.91 \pm 0.11$ & $3.53 \pm 0.07$ & $3.84 \pm 0.08$ & $3.79 \pm 0.10$ \\
SFA & $46.70 \pm 0.47$ & $47.72 \pm 0.65$ & $46.48 \pm 0.25$ & $46.37 \pm 0.61$ & $46.47 \pm 0.49$ \\
UFA & $53.30 \pm 0.74$ & $52.28 \pm 0.62$ & $53.52 \pm 0.37$ & $53.63 \pm 0.99$ & $53.53 \pm 0.49$ \\
\hline & & & & &
\end{tabular}

SFA: Saturated fatty acids.

UFA: Unsaturated fatty acids.

\section{Conclusions}

The present work confirmed that enzymatic hydrolysis could serve as an effective and economical approach to produce protein hydrolysates, collagen, and lipids from meat waste, thereby allowing to obtain additional value from the meat processing chain. 
The results of the present study revealed that it is possible to alter the degree of hydrolysis, and consequently the obtained products, by selecting the enzyme for catalyzing the hydrolysis reaction. Serine-type endopeptidases from bacterial sources (such as Alcalase or Protamex) emerged as the most suited ones for producing high-quality protein hydrolysates. The recovery of collagen was favored by the metalloendopeptidases such as Neutrase that are derived from bacterial sources. A greater release of lipids could be achieved using Alcalase compared to when using Neutrase. Moreover, the fatty acid profile of the meat waste remained unaffected by the type of protease used for hydrolysis, suggesting that hydrolysis using proteases is an effective means of recovering lipids without affecting their quality.

\section{Acknowledgments}

The authors gratefully acknowledge the financial support of the Junta de Castilla y León (Project SA058G18).

\section{Author Contributions}

Michelle Szucs: Hydrolysis experiments, data analysis, writing - original draft, Miguel Angulo: Chemical and chromatographic analysis, Carlos Costa: Chromatographic analysis assistance, $\mathrm{M}^{\mathrm{a}}$ Carmen Márquez: Development of overall experimental plan, revision of preliminary reporting, critical interpretation of results, manuscript preparation.

\section{Funding}

This work was supported financially by the Junta de Castilla y León (Project SA058G18).

\section{Competing Interests}

The authors have declared that no competing interests exist.

\section{References}

1. Gustavsson J, Cederberg C, Sonesson U, van Otterdijk R, Meybeck A. Global food losses and food waste. Rome, Italy: Food and Agriculture Organization of the United Nations; 2011.

2. Parfitt J, Barthel M, Macnaughton S. Food waste within food supply chains: Quantification and potential for change to 2050. Philos Trans R Soc B Biol Sci. 2010; 365: 3065-3081.

3. García AJ, Esteban MB, Márquez MC, Ramos P. Biodegradable municipal solid waste: Characterization and potential use as animal feedstuffs. Waste Manage. 2005; 25: 780-787.

4. Arvanitoyannis I, Ladas D. Meat waste treatment methods and potential uses. Int J Food Sci Technol. 2008; 43: 543-559.

5. Jayathilakan K, Sultana K, Radhakrishna K, Bawa AS. Utilization of byproducts and waste materials from meat, poultry and fish processing industries: A review. J Food Sci Technol. 2012; 49: 278-293.

6. Pasupuleti VK, Holmes C, Demain AL. Applications of protein hydrolysates in biotechnology. In: Protein hydrolysates in biotechnology. New York: Springer Science \& Business Media; 2014. p. 1-9. 
7. Clemente A. Enzymatic protein hydrolysates in human nutrition. Trends Food Sci Technol. 2000; 11: 254-262.

8. Manninen AH. Protein hydrolysates in sports nutrition. Nutr Metab. 2009; 6: 1-5.

9. Ścibisz M, Arct J, Pytkowska K. Protein hydrolysates in cosmetics production, part II. SÖFW J Wydanie Polskie. 2008; 1: 12-20.

10. Ramshaw JA. Biomedical applications of collagens. J Biomed Mater Res B Appl Biomater. 2016; 104: 665-675.

11. Sionkowska A, Skrzyński S, Śmiechowski K, Kołodziejczak A. The review of versatile application of collagen. Polym Adv Technol. 2017; 28: 4-9.

12. Sionkowska A, Adamiak K, Musiał K, Gadomska M. Collagen based materials in cosmetic applications: A review. Materials. 2020; 13: 4217.

13. Patel MR, Chitte PS, Bharambe DP. Oleic acid based polymeric flow improvers for Langhnaj (North Gujarat, India) crude oil. Egypt J Pet. 2017; 26: 895-903.

14. Kombe GG. Chemical modification of high free fatty acid oils for biodiesel production. In: Fatty acids. Chemistry, synthesis, and applications. Amsterdam, Netherlands: Elsevier; 2017. p. 305327.

15. Compher CW, Kinosian BP, Rubesin SE, Ratcliffe SJ, Metz DC. Energy absorption is reduced with oleic acid supplements in human short bowel syndrome. J Parenter Enteral Nutr. 2009; 33: 102108.

16. Kelm GR, Wickett RR. The role of fatty acids in cosmetic technology. In: Fatty acids. Chemistry, synthesis, and applications. Amsterdam, Netherlands: Elsevier; 2017. p. 385-404.

17. Dembitsky VM, Kuklev DV. Acetylenic epoxy fatty acids: Chemistry, synthesis and their pharmaceutical applications. In: Fatty acids. Chemistry, synthesis, and applications. Amsterdam, Netherlands: Elsevier; 2017. p. 121-146.

18. Hayes DG. Fatty acids-based surfactants and their uses. In: Fatty acids. Chemistry, synthesis, and applications. Amsterdam, Netherlands: Elsevier; 2017. p. 355-384.

19. Kristinsson HG, Rasco BA. Kinetics of the hydrolysis of Atlantic salmon (Salmo salar) muscle proteins by alkaline proteases and a visceral serine protease mixture. Process Biochem. 2000; 36: 131-139.

20. Aspmo SI, Horn SJ, Eijsink VGH. Enzymatic hydrolysis of Atlantic cod (Gadus morhua L.) viscera. Process Biochem. 2005; 40: 1957-1966.

21. AOAC. Official method of analysis. 18th ed. Washington DC: Association of Official Analytical Chemists; 2005.

22. Adler-Nissen J. Enzymic Hydrolysis of Food Proteins. London: Elsevier Applied Science; 1986.

23. AOAC. Official method of analysis. 16th ed. Washington, DC: Association of Official Analytical; 2002.

24. Pearson AM, Young RB. Muscle and meat biochemistry. Cambridge, Massachusetts: Academic Press; 1989. p. 342- 362.

25. Rogers HJ, Weidmann SM, Parkinson A. Studies on the skeletal tissues. II. The collagen content of bones from rabbits, oxen and humans. Biochem J. 1952; 50: 537-542.

26. Aldai N, Osoro K, Barrón L, Nájera Al. Gas-liquid chromatographic method for analysing complex mixtures of fatty acids including conjugated linoleic acids (cis9trans 11 and trans10cis12isomers) and long-chain ( $n-3$ or $n-6)$ polyunsaturated fatty acids: Application to the intramuscular fat of beef meat. J Chromatogr A. 2006; 1110: 133-139. 
27. Ali Z, Waheed A, Iqbal H, Siddiqui S, Parveen Z. Trans fat, fatty acids and characteristics of slaughtered buffalo waste fat by edible rendering. Buffalo Bull. 2016; 35: 199-208.

28. Bianchi M, Petracci M, Cavani C. The influence of linseed on rabbit meat quality. World Rabbit Sci. 2009; 17: 97-107.

29. Bustamante CA. Comparación del perfil de ácidos grasos, contenido de grasa y proteína de la carne de búfalo respecto a la carne de vacuno. Facultad de Zootecnia. Bogotá: Universidad de La Salle; 2005.

30. Cortinas L. Niveles de ácidos grasos poliinsaturados y $\alpha$-tocoferol en el pienso de broilers: Equilibrio entre composición lipídica y estabilidad oxidativa de la carne. Barcelona: Universitat Autònoma; 2005.

31. Cruz-González MI, Sánchez-Machado DI, López-Cervantes J, Munguia-Xochihua JA, MolinaBarrios RM, Rivera-Acuña $F$, et al. Caracterización del perfil de ácidos grasos en carne de borrego de engorda utilizando cromatografía de gases. Nacameh. 2014; 8: 39-49.

32. Daza A, Rey Al, López-Carrasco C, López-Bote CJ. Influence of feeding system on growth performance, carcass characteristics and meat and fat quality of Avileña-Negra Ibérica calves' breed. Span J Agric Res. 2014; 12: 409-418.

33. Esquivelzeta C, Casellas J, Fina M, Campo MM, Piedrafita J. Carcass traits and meat fatty acid composition in Mediterranean light lambs. Can J Anim Sci. 2017; 97: 734-741.

34. Ferreira A, Duarte J, Neto AJ, Fiorentini G, Berchielli TT. Fatty acid profile, meat quality, and carcass traits of Nellore young bulls fed different sources of forage in high-concentrate diets with crude glycerin. Rev Bras Zootec. 2016; 45: 165-173.

35. Ladeira MM, Santarosa LC, Chizzotti ML, Ramos EM, Machado OR, Oliveira DM, et al. Fatty acid profile, color and lipid oxidation of meat from young bulls fed ground soybean or rumen protected fat with or without monensin. Meat Sci. 2014; 96: 597-605.

36. Monje R, Campos H. Tabla de composición de alimentos de Costa Rica: Ácidos grasos. San José, Costa Rica: Sepan; 2006.

37. Montoya C, García JF, Barahona R. Contenido de ácidos grasos en carne de bovinos cebados en diferentes sistemas de producción en el trópico colombiano. Vitae. 2015; 22: 205-214.

38. Moo-Huchin V, Chi-Kuk M, Sauri-Duch E, Moo-Huchin M, Estrada-Mota I, Estrada-León R. Composición de ácidos grasos de la carne de ovinos de pelo. XL Reunión de la Asociación Mexicana para la Producción Animal y Seguridad Alimentaria, A.C. y IX Seminario Internacional de Ovinos en el Trópico, 2013; 875-878.

39. Muchenje V, Dzama K, Chimonyo M, Strydom PE, Hugo A, Raats JG. Some biochemical aspects pertaining to beef eating quality and consumer helath: A review. Food Chem. 2009; 112: 279289.

40. Real M. Caracterización en ácidos grasos de la carne de corderos del Partido de Puan (Buenos Aires, Argentina). Vet Arg. 2018; XXXV: 1-10.

41. Sosa AR, Montero M, Juárez FI. Fatty acids and conjugated linoleic acids content in beef cattle. Rev Electron Vet. 2009; 10: 1-83.

42. Safari R, Motamedzadegan A, Ovissipour M, Regenstein JM, Gildberg A, Rasco B. Use of hydrolysates from yellowfin tuna (thunnus albacares) heads as a complex nitrogen source for lactic acid bacteria. Food Bioproc Tech. 2012; 5: 73-79. 
43. Baez-Suarez AJ, Ospina-de-Barreneche N, Ospina-de-Barreneche N, Zapata-Montoya JE. Efecto de temperatura, $\mathrm{pH}$, concentración de sustrato y tipo de enzima en la hidrólisis enzimática de vísceras de tilapia roja (Oreochromis spp.). Inf Tecnol. 2016; 27: 63-76.

44. Fallah M, Bahram S, Javadiam SR. Fish peptone development using enzymatic hydrolysis of silver carp by-products as a nitrogen source in Staphylococcus aureus media. Food Sci Nutr. 2015; 3: 153-157.

45. Bhaskar N, Benila T, Radha C, Lalitha RG. Optimization of enzymatic hydrolysis of visceral waste proteins of Catla (Catla catla) for preparing protein hydrolysate using a commercial protease. Bioresour Technol. 2008; 99: 335-343.

46. Guérard F, Dufossé L, De La Broise D, Binet A. Enzymatic hydrolysis of proteins from yellowfin tuna (Thunnus albacares) wastes using Alcalase. J Mol Catal B Enzym. 2001; 11: 1051-1059.

47. Camacho F, Gonzalez-Tello P, Guadix EM, Pardo F. Hidrolizados enzimáticos de proteínas para nutrición enteral: Cinética de la hidrólisis. Acta-A. 1997; VII: 31-37.

48. Guadix A, Guadix EM, Páez-Dueñas MP, González-Tello P, Camacho F. Procesos tecnológicos y métodos de control en la hidrólisis de proteínas. Ars Pharm. 2000; 41: 79-89.

49. Cox MM, Nelson DL. Lehninger Principios de bioquímica. 5th ed. Barcelona: Ediciones Omega; 2007.

50. Adler-Nissen J. Enzymatic hydrolysis of proteins for increases solubility. J Agr Food Chem. 1976; 24: 1090-1093.

51. Leduc A, Fournier V, Henry J. A standardized, innovative method to characterize the structure of aquatic protein hydrolysates. Heliyon. 2020; 6: e04170.

52. Calvo M. Bioquímica de los alimentos. Zaragoza: Zaragoza University; 2021 [cited date 2021 May 10]. Available from: http://milksci.unizar.es/bioquimica/temas/proteins/colageno.html.

53. Hema GS, Joshy CG, Shyni K, Chatterjee NS, Ninan G, Mathew S. Optimization of process parameters for the production of collagen peptides from fish skin (Epinephelus malabaricus) using response surface methodology and its characterization. J Food Sci Technol. 2017; 54: 488496.

54. Iltchenko S, Kempka AP, Prestes RC. Profiles of enzymatic hydrolysis od different collagens and derivates over time. Rev Bras Tecnol Agroindustr. 2017; 11: 2165-2185.

55. Hartina MR, Kuan AY, Wolyna P, Lee JS, Izzreen MN. Effects of different enzymatic treatment on the properties of hydrolyzed collagen from pangasius fish (Pangasius hypophthalmus). Proceedings of the International Conference on Food Science and Nutrition; 2017 June 26-27; Baltimore, United States.

56. Batista I, Ramos C, Mendonca R, Nunes L. Enzymatic hydrolysis of sardine (Sardina pilchardus) by-products and lipid recovery. J Aquat Food Prod Technol. 2009; 18: 120-134.

57. Meng Z, Wei S, Qi K, Guo Y, Wang Y, Liu Y. Secondary structure of proteins on oil release in aqueous enzymatic extraction of rapeseed oil as affected hydrolysis state. Int J Food Prop. 2018; 21: 119-127.

58. Hathwar SC, Bijinu B, Rai AK, Narayan B. Simultaneous recovery of lipids and proteins by enzymatic hydrolysis of fish industry waste using different commercial proteases. Appl Biochem Biotechnol. 2011; 164: 115-124. 


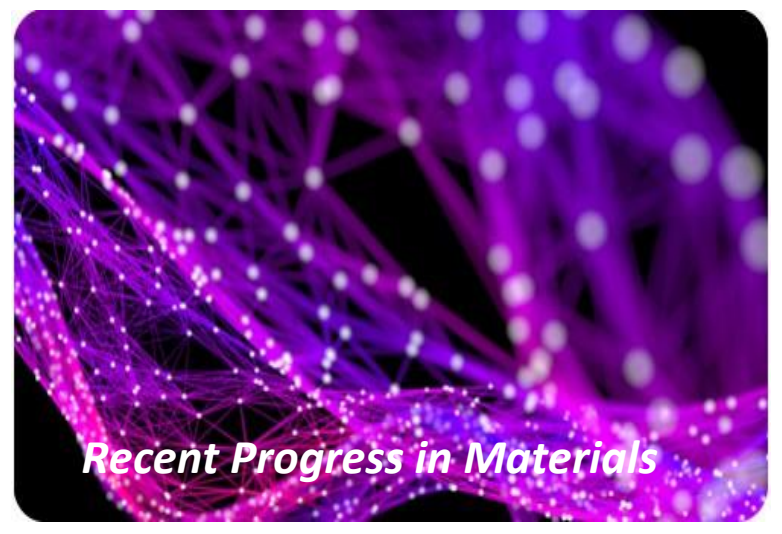

Enjoy Recent Progress in Materials by:

1. Submitting a manuscript

2. Joining in volunteer reviewer bank

3. Joining Editorial Board

4. Guest editing a special issue

For more details, please visit:

http://www.lidsen.com/journals/rpm 